\title{
GAMBARAN PIO SWAMEDIKASI APOTEKER DALAM PENATALAKSANAAN FLU
}

\author{
Hilda Suherman $^{1)}$, Dina Febrina ${ }^{2)}$ \\ ${ }^{1), 2)}$ Program Studi Farmasi Sekolah Tinggi Ilmu Kesehatan Harapan Bangsa Purwokerto \\ 1) hildasuherman@shb.ac.id, ${ }^{2)}$ dinafebrina@ @shb.ac.id
}

\begin{abstract}
Abstrak
Swamedikasi adalah upaya manusia untuk mengobati penyakit atau gejala penyakit ringan seperti demam, batuk, flu, nyeri dan lain-lain tanpa resep dokter. Pada pelaksanaannya, keterbatasan pengetahuan akan obat dan penggunaannya dapat menjadi sumber kesalahan pengobatan (medication error). Penelitian ini dilakukan dengan metode penelitian deskriptif cross sectional. Data dikumpulkan melalui teknik pengisian kuesioner yang telah divalidasi. Sebanyak 300 orang responden yang terlibat dalam penelitian ini dipilih dengan metode consecutive sampling dari 3 apotek di Kota Purwokerto yang ditentukan secara proporsional sesuai dengan populasi masingmasing apotek. Data dianalisis dengan uji Chi-square dan uji Fisher menggunakan Statistical Product and Servicer Solution (SPSS) versi 17. Hasil penelitian menunjukkan bahwa tingkat pengetahuan pasien 22,6\% tergolong buruk, $48 \%$ tergolong sedang, dan 29,4\% tergolong baik. Penggunaan obat swamedikasi $26,3 \%$ tidak rasional dan $73,7 \%$ rasional. Berdasarkan hasil penelitian diperoleh bahwa tingkat pengetahuan pasien tergolong sedang dengan persentase $48 \%$. Sedangkan rasionalitas swamedikasi tergolong rasional dengan persentase $73,7 \%$.
\end{abstract}

Kata Kunci: Swamedikasi, Apotek, Pengetahuan, Rasionalitas penggunaan obat

\begin{abstract}
Self-medication is a human effort to treat diseases or symptoms of minor ailments such as fever, cough, flu, pain and others without a doctor's prescription. In practice, limited knowledge of drugs and their use can be a source of medication errors (medication error). This research was conducted with a cross sectional descriptive research method. Data was collected through a validated questionnaire filling technique. A total of 300 respondents involved in this study were selected by consecutive sampling method from 3 pharmacies in the city of Purwokerto which were determined proportionally according to the population of each pharmacy. Data were analyzed by Chi-square test and Fisher's test used Statistical Product and Servicer Solution (SPSS) version 17. The results showed that the patient's knowledge level was $22.6 \%$ classified as poor, $48 \%$ classified as moderate, and $29.4 \%$ classified as good. The use of self-medication is $26.3 \%$ irrational and $73.7 \%$ rational. Based on the results of the study, it was found that the patient's level of knowledge was classified as moderate with a percentage of $48 \%$. While self-administered rationality is classified as rational with a percentage of $73.7 \%$.
\end{abstract}

Keywords: Self-medication, Pharmacy, Knowledge, Rationality of drug use 


\section{PENDAHULUAN}

Pengobatan sendiri (self medication) merupakan upaya yang paling banyak dilakukan masyarakat untuk mengatasi keluhan atau gejala penyakit sebelum mereka memutuskan mencari pertolongan ke pusat pelayanan kesehatan/petugas kesehatan (Depkes RI, 2008). Mengobati diri sendiri atau yang lebih dikenal dengan swamedikasi berarti mengobati segala keluhan dengan obat-obatan yang dapat dibeli bebas di apotek atau toko obat dengan inisiatif atau kesadaran diri sendiri tanpa nasehat dokter (Muharni, 2015). Berdasarkan hasil Riset Kesehatan Dasar (Riskesdas) 2013，35,2\% rumah tangga menyimpan obat untuk swamedikasi (Kemenkes RI, 2015).

Swamedikasi biasanya dilakukan untuk mengatasi keluhan-keluhan dan penyakit ringan yang banyak dialami masyarakat, seperti demam, nyeri, pusing, batuk, influenza, sakit maag, kecacingan, diare, penyakit kulit dan lain-lain (Depkes RI, 2006). Salah satu penyebab tingginya tingkat swamedikasi adalah perkembangan teknologi informasi via internet. Alasan lain adalah karena semakin mahalnya biaya pengobatan ke dokter, tidak cukupnya waktu yang dimiliki untuk berobat, atau kurangnya akses ke fasilitas-fasilitas kesehatan (Gupta, et al., 2011; Hermawati, 2012).

Swamedikasi harus dilakukan sesuai dengan penyakit yang dialami, pelaksanaannya sedapat mungkin harus memenuhi kriteria penggunaan obat yang rasional. Kriteria obat rasional antara lain ketepatan pemilihan obat, ketepatan dosis obat, tidak adanya efek samping, tidak adanya kontraindikasi, tidak adanya interaksi obat, dan tidak adanya polifarmasi (Muharni, 2015).

Sampai saat ini di tengah masyarakat seringkali dijumpai berbagai masalah dalam penggunaan obat. Diantaranya ialah kurangnya pemahaman tentang penggunaan obat tepat dan rasional, penggunaan obat bebas secara berlebihan, serta kurangnya pemahaman tentang cara menyimpan dan membuang obat dengan benar. Sedangkan tenaga kesehatan masih dirasakan kurang memberikan informasi yang memadai tentang penggunaan obat (Kemenkes RI, 2015). Oleh karena itu, sebagai pelaku selfmedication harus mampu mengetahui jenis obat yang diperlukan, kegunaan dari tiap obat, menggunakan obat dengan benar (cara, aturan pakai, lama pemakaian), mengetahui efek samping obat yang digunakan dan siapa yang tidak boleh 
menggunakan obat tersebut (Depkes RI, 2008).

\section{METODOLOGI}

\section{A. Jenis Penelitian}

Penelitian ini merupakan penelitian deskriptif yang menggambarkan fenomena yang diteliti yang terjadi di dalam suatu populasi tertentu, menggunakan desain pendekatan crosssectional (Swarjana,2012).

\section{B. Lokasi dan Waktu Penelitian}

\section{Lokasi penelitian}

Penelitian ini dilaksanakan di tiga apotek di Kota Purwokerto. Apotek dipilih berdasarkan lokasi yang strategis dan pemilik apotek yang bersedia memberikan izin untuk dilakukannya penelitian.

\section{Waktu penelitian}

Penelitian ini dilaksanakan pada bulan 23 Mei 2018 dari jam 09.00 s/d 21.00 WIB di tiga apotek di Kota Purwokerto.

\section{Populasi dan Sampel}

\section{Populasi}

Pada penelitian ini populasi yang digunakan adalah semua pasien swamedikasi berusia 18 - 60 tahun dari tiga apotek di Kota Purwokerto.

\section{Sampel}

Sampel dalam penelitian ini adalah pasien swamedikasi berusia $18-60$ tahun dari tiga apotek di Kota Purwekerto yang memenuhi kriteria inklusi. Pengambilan sampel dilakukan dengan metode consecutive sampling sampai jumlah sampel yang dibutuhkan terpenuhi serta berdasarkan waktu pengumpulan data yang tersedia (Swarjana, 2012).

Kriteria inklusi :

a. pasien yang datang ke apotek untuk melakukan swamedikasi.

b. pasien berumur $18-60$ tahun.

c. pasien yang dapat berkomunikasi dengan baik.

Kriteria eksklusi :

a. pasien yang tidak bersedia bekerja sama dalam penelitian ini.

\section{Pengambilan Data}

Sumber data dalam penelitian ini yaitu data primer yang diperoleh secara langsung dari responden melalui pengisian kuesioner. Kuesioner dalam penelitian ini terdiri dari 4 bagian, yaitu bagian pendahuluan untuk mengetahui: apakah pasien pernah menggunakan obat swamedikasi, bagian pengetahuan swamedikasi bertujuan untuk 
mengetahui tingkat pengetahuan pasien tentang swamedikasi, bagian rasionalitas swamedikasi bertujuan untuk mengetahui rasionalitas obat swamedikasi yang digunakan responden dan bagian data demografi responden yang bertujuan untuk mengetahui karakteristik responden. Kuesioner yang digunakan sebelumnya dilakukan uji validitas dan reliabilitas.

\section{E. Analisis Data}

Tingkat pengetahuan dibagi menjadi 3 kategori yaitu tingkat pengetahuan baik (skor $<60 \%$ ), sedang (skor 60\%-80\%) dan buruk (skor >80\%). Sedangkan rasionalitas dikategorikan menjadi 2

\section{HASIL DAN PEMBAHASAN}

Flu adalah suatu infeksi saluran pernapasan atas. Orang dengan daya tahan tubuh yang tinggi biasanya sembuh sendiri tanpa obat. Pada anak-anak, lanjut usia dan orang yang memiliki daya tahan tubuh rendah lebih cenderung menderita komplikasi seperti infeksi bakteri sekunder. Flu ditularkan melalui percikan udara pada saat batuk, bersin, dan tangan yang tidak dicuci setelah kontak dengan cairan 16 hidung/mulut.Infeksi saluran pernafasan bagian atas disebabkan oleh virus influenza.

Berdasarkan hasil penelitian ini, keluhan yang paling banyak dialami yaitu rasional jika memenuhi enam kriteria ketepatan pengobatan sendiri dan tidak rasional jika tidak memenuhi enam kriteria ketepatan pengobatan sendiri. Dilakukan pengolahan data menggunakan SPSS. Analisis data dilakukan melalui 2 tahap, yaitu analisis univariat, digunakan untuk mendapatkan gambaran distribusi frekuensi karakteristik demografi dan variabel lain. Analisis bivariat, digunakan untuk mengetahui hubungan sosiodemografi dengan tingkat pengetahuan tentang swamedikasi dan rasionalitas swamedikasi menggunakan uji chi-square dan fisher.

responden adalah flu (16,9\%). Adapun flu disertai demam sebanyak 3,4\%; flu disertai batuk sebanyak 5,4\%; dan flu disertai nyeri sebanyak 0,6\%. Data lengkap dapat dilihat pada Tabel 1.

Tabel 1. Keluhan Penyakit yang dialami Responden

\begin{tabular}{|l|c|c|}
\hline $\begin{array}{c}\text { Keluhan } \\
\text { Penyakit }\end{array}$ & Frekuensi & $\begin{array}{c}\text { Persentase } \\
(\%)\end{array}$ \\
\hline Flu & 48 & 16,9 \\
\hline Flu + Demam & 11 & 3,4 \\
\hline Flu + Batuk & 15 & 5,4 \\
\hline Flu + Nyeri & 2 & 0,6 \\
\hline
\end{tabular}


Pengobatan sendiri adalah upaya yang dilakukan orang awam untuk mengatasi sakit atau keluhan yang dialaminya, tanpa bantuan tenaga ahli medis (Supardi, 2008). Namun bukan berarti asal mengobati, justru pasien harus mencari informasi obat yang sesuai dengan penyakitnya dan salah satunya apoteker memiliki peranan di sini. Apoteker bisa memberikan informasi obat yang objektif dan rasional. Pengobatan sendiri boleh dilakukan untuk kondisi penyakit ringan, umum dan tidak akut (Wulandari, 2010). Hasil ini sejalan dengan pendapat Young (1980) bahwa kriteria yang dipakai untuk memilih sumber pengobatan salah satunya adalah jarak ke sumber pengobatan dan Nadesul (2009) bahwa salah satu alasan penghematan dan efisiensi tindakan pengobatan sendiri banyak dilakukan orang karena dengan sendirinya sakit ringan akan sembuh bila tidak diobati. Seperti jika batuk, flu, pening, mulas dan lain-lain. Selain itu alasan dekat rumah, harga terjangkau dan informasi lebih jelas didukung pengetahuan dan wawasan medis yang semakin banyak, upaya pengobatan sendiri menjadi pilihan untuk efisiensi.

Terkait dengan pengobatan sendiri penyakit flu, hal ini sejalan dengan penelitian yang dilakukan oleh Sjamsulhidayat, (1990) yang menujukkan kelompok terapi obat yang paling banyak digunakan di masyarakat berdasarkan urutan terbanyak adalah obat flu. Demikian juga shankar et al (2003) yang mendapatkan bahwa obat flu memiliki persentase terbanyak digunakan dalam pengobatan sendiri.

Dengan demikian akses ke sumber informasi pelayanan obat mudah dijangkau baik dengan jalan kaki maupun dengan kendaraan. Pada penelitian ini sumber informasi pelayanan obat terletak pada lokasi yang dekat dengan pemukiman responden. Dengan demikian, semakin dekat jarak rumah tinggal dengan sumber pelayanan informasi obat maka akan semakin besar pengobatan sendiri penyakit flu.

\section{KESIMPULAN}

Tingkat pengetahuan pasien tentang swamedikasi di tiga apotek Kecamatan Medan Sunggal, mayoritasnya adalah tingkat pengetahuan tergolong sedang (48\%). Rasionalitas swamedikasi pasien di tiga apotek Kecamatan Medan Sunggal yaitu tergolong rasional $(73,7 \%)$.

\section{SARAN}

Berdasarkan hasil ini diharapkan masyarakat dapat lebih bijak dalam memilih obat dalam melakukan swamedikasi untuk penyakit flu. 


\section{DAFTAR PUSTAKA}

Anief. (1997). Apa yang Perlu Diketahui tentang Obat. Yogyakarta: Gajah Mada

University Press.

Badan Pusat Statistik. (2015). Medan Sunggal dalam Angka 2015. Medan: Badan

Pusat Statistik Kota Medan.

Bogadenta, A. (2012). Manajemen

Pengelolaan Apotek. Yogyakarta: DMedika.

Hal. 18-19.

Depkes RI. (2006). Pedoman Penggunaan

Obat Bebas dan Terbatas. Jakarta:

Departemen Kesehatan Republik Indonesia. Hal. 8, 22-37, 31-35, 38-41, 47-50.

Depkes RI. (2008). Materi Pelatihan Peningkatan Pengetahuan dan Keterampilan Memilih Obat Bagi Tenaga Kesehatan. Jakarta: Departemen Kesehatan Republik Indonesia. Hal. 0, 6-8, 9, 10.

Garofalo, L., Gabriella D. G., dan Italo, F. A. (2015). Self Medication Practice among Parents in Italy. Biomed Research International. Hal. 1-8.

Gupta, P., Bobhate, P., dan Shrivastava, S. (2011). Determinants of Self Medication Practices in an Urban Slum Community. Asian Journal Pharmaceutical and Clinical Research. 4(3): 54-57.

Harahap, N. A. (2015). Tingkat Pengetahuan dan Rasionalitas Swamedikasi di

Tiga Apotek Kota Panyabungan. Skripsi. Medan: Fakultas Farmasi Universitas Sumatera Utara.

Hermawati, D. (2012). Pengaruh Edukasi Terhadap Tingkat Pengetahuan dan Rasionalitas Penggunaan Obat Swamedikasi Pengunjung di Dua Apotek Kecamatan Cimanggis, Depok. Skripsi. Fakultas
Matematika dan Ilmu Pengetahuan Alam Program Studi Farmasi UI.

Kemenkes RI. (2015). Pemahaman Masyarakat Akan Penggunaan Obat Masih

Rendah. Jakarta: Pusat Komunikasi Publik.

Keputusan Menteri Kesehatan RI No. 347/Menkes/SK/VII/1990 tentang Obat

Wajib Apotek. Jakarta: Departemen Kesehatan RI.

Keputusan Menteri Kesehatan

1176/MENKES/SK/X/1999 tentang

Daftar Obat Wajib Apotek No.3. Jakarta: Departemen Kesehatan RI.

Khomsan, A. (2000). Teknik Pengukuran Pengetahuan Gizi. Bogor:

Departemen

Gizi dan Sumber daya Keluarga, Fakultas Pertanian IPB. Hal. 11. Universitas Sumatera Utara

Kristina, S., Prabandari, Y., dan Sudjaswadi, R. (2008). Perilaku Pengobatan Sendiri Yang Rasional Pada Masyarakat. Majalah Farmasi Indonesia. Yogyakarta: Fakultas Farmasi. Universitas Gajah Mada. 19(1): 32-40.

Lapau, B. (2012). Metode Penelitian Kesehatan: Metode Ilmiah Penulisan Skripsi, Tesis, dan Disertasi. Edisi Revisi. Jakarta: Pustaka Obor Indonesia. Hal. 42.

Lwanga, S. K., dan Lameshow, S. (1991). Sampel Size Determination in Health

Studies. Geneva: World Health Organization. Hal. 25.

Mellina, I. (2016). Tingkat Pengetahuan Pasien dan Rasionalitas Swamedikasi di

Empat Apotek Kecamatan Medan Marelan. Skripsi. Medan: Fakultas Farmasi Universitas Sumatera Utara.

Menkes RI. (2016). Peraturan Menteri Kesehatan No. 73 Tahun 2016 tentang 
Standar Pelayanan Kefarmasian di Apotek. Jakarta: Departemen Kesehatan RI.

Mubarak, W. I., dkk. (2007). Promosi Kesehatan: Sebuah Pengantar Proses Belajar Mengajar dalam Pendidikan. Yogyakarta: Graha Ilmu. Hal. 83-84.

Muharni, S., Fina, A., dan Maysharah, M. (2015). Gambaran Tenaga Kefarmasian dalam Memberikan Informasi Kepada Pelaku Swamedikasi di ApotekApotek Kecamatan Tampan, Pekanbaru. Jurnal Sains Farmasi \& Klinis. 2(1): 47-53.

Notoatmodjo, S. (2003). Ilmu Kesehatan Masyarakat: Prinsip-Prinsip Dasar. Jakarta: Rineka Cipta. Hal. 127-130.

Peraturan Menteri Kesehatan 919/Menkes/Per/X/1993 tentang Kriteria Obat yang

Dapat Diserahkan Tanpa Resep. Jakarta: Departemen Kesehatan RI.

Peraturan Menteri Kesehatan 924/MENKES/PER/X/1993 tentang Daftar Obat Wajib Apotek No.2. Jakarta: Departemen Kesehatan RI.

Peraturan Menteri Kesehatan 925/MENKES/PER/X/1993 tentang Daftar Perubahan Golongan Obat No.1. Jakarta: Departemen Kesehatan RI.

Peraturan Menteri Kesehatan No. 9 Tahun 2017 tentang Apotek. Jakarta: Departemen Kesehatan RI. PP RI No 51. (2009). Tentang Pekerjaan Kefarmasian. Jakarta. Hal. 1-3.

Simamora, B. (2008). Panduan Riset Perilaku Konsumen. Jakarta: Gramedia Pustaka Utama. Hal. 59.

Supardi, S., dan Susyanty, A. L. (2010). Penggunaan Obat Tradisional Dalam Upaya Pengobatan Sendiri Di Indonesia (Analisis Data Susenas Tahun Universitas Sumatera Utara
2007). Buletin Penelitian

Kesehatan. Jakarta: Pusat Penelitian dan Pengembangan Sistem dan Kebijakan Kesehatan. 38(2): 80-89.

Swarjana, I. K. (2012). Metodologi Penelitian Kesehatan. Yogyakarta: CV Andi

Offset. Hal. 51, 102.

Talawo, D. P. (2014). Pengaruh Leaflet Terhadap Tingkat Pengetahuan Penggunaan Obat Swamedikasi Di Desa Tingkohubu Timur Kecamatan Suwawa. Jurnal Penelitian Farmasi. Gorontalo: Fakultas Farmasi Universitas Negeri Gorontalo. Hal. 1-12.

Trihendradi, C. (2011). Langkah Mudah Melakukan Analisis Statistik Menggunakan SPSS 19. Yogyakarta: Penerbit Andi. Hal. 145-147, 215217.

Zeenot, S. (2013). Pengelolaan dan Penggunaan Obat Wajib Apotek. Jogjakarta: D-Medika. Hal. 109112, 139 dan 143. 